J. Perinat. Med. 17 (1989) 447

\section{Biochemical timing of peri-intraventricular hemorrhage assessed by perinatal CPK-BB isoenzyme measurements}

\author{
Maurizio Amato, Petra Hüppi, Reto Gambon, and Henning Schneider \\ Division of Neonatology, Department of Obstetrics and Gynecology, University \\ of Berne, Switzerland
}

\section{Introduction}

Peri-intraventricular hemorrhage (PIVH) is the most common type of neonatal intracranial hemorrhage in preterm infants and may account for much of the subsequent morbidity in neonatal survivors with hydrocephalus, cerebral palsy or mental retardation [10]. The true timing of PIVH is a crucial information to an understanding of etiologic factors and their possible prevention [7, 12]. Transfontanelle real-time ultrasonography (US) has been used as method of choice to detect and follow PIVH [14]. With the availability of repetitive examinations it has been possible to study the optimal timing for the ultrasonographic diagnosis of hemorrhagic lesions in preterms. However, its maximal diagnostic efficiency lies between day 4 and 14 since fresh blood may initially appear sonolucent [19].

Increased levels of brain type Creatine Kinase Isoenzyme (CPK-BB) reflect cellular injury and have been found in serum of preterm neonates with PIVH [1, 4, 18]. Because of the supposed interval required for clot formation to become visible on ultrasound, we used serial measurements of serum brain-typical CPK performed in the first 60 hours of life to determine the biochemical timing of PIVH. The purpose of our study was to investigate in a group of 50 preterm infants less than $1500 \mathrm{~g}$ birth weight the usefulness of serum CPK-BB determination in the detection of PIVH and to compare the neurosonographic and biochemical timing of such cerebral lesions.

\section{Patients and methods}

From August 1987 to October 1988 fifty appropriate for gestational age infants weighing between 780 and $1480 \mathrm{~g}$ at birth (26-34 weeks gestation) and admitted to the Neonatal Intensive Care Unit (NICU) of our Neonatal Division were studied. Sequentially admitted infants were enrolled prospectively in this study after informed parental consent was obtained. All patients were inborn and those with congenital anomalies or product of multiple gestation were excluded. The gestational age was determined by maternal history, prenatal ultrasonographic assessment as well as physical and neurological assessment using the criteria of BALLARD et al [3] and by examination of the anterior capsule of the lens [2]. The patients received standard care by the attending neonatologist and therapy regimens were not altered for the purpose of this study. Details of the gestation, labor, delivery and data collected in the perinatal period including medications and all significant events such as seizures, pneumothoraces and need of assisted ventilation were recorded. Admitting diagnoses were most commonly respiratory distress syndrome (RDS) (78\%) and presumed neonatal infection $(20 \%)$. Other selected perinatal risk factors for PIVH are displayed on table I.

\subsection{Neurosonography}

Ultrasound examination of the newborn brain was performed as soon as possible after admission to the NICU. Further examinations were performed at 24 hours of life, every day in the first week and weekly thereafter until discharge. 
Table I. Selected perinatal risk factors for PIVH

\begin{tabular}{llll}
\hline Mode of delivery & $\begin{array}{l}\text { PIVH group } \\
(\mathrm{n}=15)\end{array}$ & $\begin{array}{l}\text { no PIVH group } \\
(\mathrm{n}=35)\end{array}$ & p-value \\
\hline Cesarean/vaginal & $4 / 11$ & $12(23$ & n.s.* \\
Premature rupture of membranes $(>24 \mathrm{~h})$ & $5(33 \%)$ & $11(31 \%)$ & n.s. \\
Assisted ventilation & $7(46 \%)$ & $15(42 \%)$ & n.s. \\
Pneumothorax & $1(6 \%)$ & - & - \\
Patent ductus arteriosus & $2(13 \%)$ & $4(11 \%)$ & n.s. \\
Hyaline membrane disease & $5(33 \%)$ & $9(25 \%)$ & n.s. \\
Recurrent Apnea & $9(60 \%)$ & $14(40 \%)$ & n.s. \\
Seizures & $1(6 \%)$ & $11 \%)$ & n.s. \\
Hypothermia $\left(<36.5^{\circ} \mathrm{C}\right)$ & $2(13 \%)$ & $5(17 \%)$ & n.s. \\
Hypoglycemia $(<1.1 \mathrm{mmol} / \mathrm{l})$ & $3(20 \%)$ & $5(14 \%)$ & n.s. \\
\hline
\end{tabular}

n. s. ${ }^{*}=$ not statistically significant

An ATL ultramark 4 (Advanced Technology Laboratories) sector Scanner with 5 and 7.5 $\mathrm{MHz}$ transducers was used. The scans were performed through the anterior fontanel in coronal and sagittal planes and reviewed by observers unaware of the infant's clinical course and other study findings. For classification of PIVH, Papile's grading system was used [15]: Grade I, subependymal hemorrhage; Grade 2, intraventricular hemorrhage; Grade 3, intraventricular hemorrhage with ventricular dilation; Grade 4, intraventricular hemorrhage with parenchymal involvement. The time of ultrasonographic occurrence of PIVH was calculated using the day at wich the abnormality was first detected.

\subsection{Enzyme analysis}

CPK-BB was measured in all patients immediately after delivery in capillary blood (T0) then serially at $6-10$ hours (T1), $20-30 \mathrm{~h}$ (T2) and 40-60 h (T3) of life. Heel-prick capillary blood specimens were collected in Microtainer tubes. The volume of whole blood obtained ranged from 0.3 to $0.5 \mathrm{ml}$. It was centrifugated within 30 minute after collection, serum being separated and stored at $-20^{\circ} \mathrm{C}$. The technologist performing the analysis was not aware of the subiect's condition. For determination of total CPK-BB serum activity a new and very sensitive method was used as described by BUCHER et al [6]. One to three microliters of serum were electrophoresed on cellulose acetate strips for $20 \mathrm{~min}$ at $300 \mathrm{~V}$. Using a Sigma Scanner FTR-20 connected to a Spectraphysic Integrator SP 4100 the increase of NADH was measured fluorometrically. Direct scanning of isoenzyme kinetics zone electrophoresis allows exact quantification of isoenzyme patterns.

\subsection{Statistics}

As described above, infants were grouped for purposes of data analysis according to the presence of PIVH as detected by neurosonography. The data were analysed by Chi-Square Test and unpaired Student's t-test where appropriate. $\mathbf{P}$ values $<0.05$ were considered significant.

\section{Results}

The birth weight of the 50 infants was 1120 $\pm 320 \mathrm{~g}$ and their gestational age $30 \pm 3.7$ weeks (table II). The overall incidence of PIVH was $30 \%$ (15 cases). Most commonly hemorrhage was detected in the subependymal area (8 patients, $16 \%$ ). PIVH Grade 2 was observer in six infants $(12 \%)$. Only one patient $(2 \%)$ had PIVH Grade 3 with ventricular dilation. No cerebral parenchymal involvement was observed. None of the infants died during the study period. The infants were evaluated for the presence or absence of a number of risk factors according to PIVH grouping. The infants with no PIVH were found to have significantly higher gestational age $(p<0.05)$ and significantly higher Apgar Scores at one minute of life $(p<0.05)$. There were no significant differences in birth weights, Apgar 
Table II. Perinatal characteristics of study subjects (Values are Mean \pm SD)

\begin{tabular}{|c|c|c|c|}
\hline Perinatal feature & $\begin{array}{l}\text { PIVH group } \\
(\mathrm{n}=15)\end{array}$ & $\begin{array}{l}\text { no PIVH group } \\
(\mathrm{n}=35)\end{array}$ & p-value \\
\hline Male: Female & $6: 9$ & $17: 18$ & n. s.* \\
\hline Birth weight (g) & $1080 \pm 360$ & $1110 \pm 340$ & n.s. \\
\hline Gestational age $(w)$ & $28.2 \pm 2.6$ & $31.3 \pm 2.4$ & $<0.05$ \\
\hline \multicolumn{4}{|l|}{ Apgar Score } \\
\hline 1 minute & $3.7 \pm$ & $6.8 \pm$ & $<0.05$ \\
\hline 5 minute & $7.4 \pm$ & $8.1 \pm$ & n.s. \\
\hline Arterial cord blood $\mathrm{pH}$ & $7.18 \pm$ & $7.21 \pm \quad 0.1$ & n.s. \\
\hline $\mathrm{T}_{0}$ CPK-BB level (U/1) & $70.8 \pm 30.5$ & $20.9 \pm 10.7$ & $<0.05$ \\
\hline
\end{tabular}

n. $.^{*}=$ not statistically significant

Scores at five minutes of life, cesarean section, need and duration of assisted ventilation, pneumothoraces and apneic spells among the two groups of babies. Sex distribution reflected all nursery admissions ( 23 boys, 27 girls). The age of onset of PIVH was less than 24 hours in two infants (13\%), 24 to 48 hours in three $(20 \%), 48$ to 72 hours in nine $(60 \%)$ and 72 to 96 hours in one patient $(6 \%)$. No PIVH developed after this time and no extension of the original bleeding was observed in any case. Ultrasound evidence of resolution of the hemorrhage occurred as early as ten days and as late as three months after PIVH was first diagnosed. Ventricular dilation first diagnosed in the patient with Grade 3 PIVH on day 12 of life was moderate without progression of the initial degree and resolved within two months after occurrence. To determine the optimal timing for diagnostic ultrasound we looked at the percentage of PIVH detected at each scanning interval among the number of patients with PIVH. Maximal diagnostic efficiency for PIVH was on day three of life $(60 \%$ of the studied infants with PIVH were detected on US on this time). The subjects with PIVH had an average CPK-BB level at to more than three times that of patients without PIVH. At delivery, the 15 patients with proven PIVH on ultrasound had mean CPK-BB values of $70.8 \pm 30.5 \mathrm{U} / 1 \mathrm{com}$ pared to $20.9 \pm 10.7 \mathrm{U} / 1$ in the group without PIVH $(\mathrm{p}<0.05)$ (table II). No significant difference was present on similar analyses performed at $6-10 \mathrm{~h}(\mathrm{~T} 1), 20-30 \mathrm{~h}(\mathrm{~T} 2)$ and $40-60 \mathrm{~h}$ (T3) of life. In $73 \%$ (11 cases) of the analyses performed on these three last times (T1, T2, T3), CPK-BB isoenzyme was not present. In only four cases $(26 \%)$ serum CPK-BB levels were very low at $\mathrm{T} 1$ but the difference between the two groups of patients was not statistically significant (mean values $10.7 \pm 2.9$ vs $9.6 \pm 3.4 \mathrm{U} / \mathrm{l})(\mathrm{p}>0.05)$. Only subjects with CPK-BB values greater than $30 \mathrm{U} / 1$ at birth were at high risk to develop PIVH detected then by neurosonography on the third day of life. In this study we did not search for a correlation between CPK-BB level and degree of PIVH.

\section{Discussion}

In view of current interest to establish the predictive value of perinatal risk factors associated with PIVH, it is of interest to note that previous studies using real-time ultrasound scanning report maximal efficiency for diagnosis of PIVH on day $14[16,20]$. Significant intraventricular hemorrhage may be missed by ultrasound, particularly if ultrasound scan is obtained within few days of the time of hemorrhage since fresh blood may initially appear sonolucent [5]. As a fibrin clot organizes, it becomes visible as a bright echo. Because of the interval required for clot formation, serial ultrasound examinations of the infant for up to four days of age may be required to detect the presence of hemorrhage. TsIANTOS et al [21] routinely labeled erythrocytes of neonates with Chromium 51 within the first few hours of life and found that $60 \%$ of the hemorrhages took place between 15 and 48 hours of age. FUJIMURA et al [9] using hemoglobin as a marker, observed that infants less than 28 week's gestation were more likely to sustain PIVH in the first 24 hours of life than infants of greater gestational age. The authors concluded 
that these early hemorrhages are common in very low birth weight infants and that they are probably related to adverse parinatal factors. Although we did not observe in our collective such division of timing in relation to gestational age, we speculated that perinatal factors are the prevalent cause of PIVH and that they are more important than neonatal factors with regard to the etiology of PIVH [13]. However, performing the first ultrasound examination as soon as possible after delivery (within the first six hours of life) in only two cases we were able to demonstrate an hemorrhage at this time. In the other 13 studied cases we were not able to diagnose PIVH before the third day of life. Our hypothesis on earlier timing of PIVH in preterm infants was proved using serial CPK-BB evaluations. Several studies have shown that measurements of CPK$\mathrm{BB}$ activity is useful for prognosis in neonate at risk of brain damage $[8,22]$. In adults this brain specific enzyme is significantly present in serum of patients following cerebrovascular injury. In our study, preterm infants with PIVH have also significant elevations in serum levels of CPK-BB at birth. Although it is known that CPK-BB is present in small amounts in the lung, intestine, kidney and placenta, it is demonstrated that any disorder that injuries CNS cells results in a considerable elevation of enzymatic levels that can be detected in the cerebrospinal fluid and in serum [5]. In preterm infants PIVH accounts for the majority of CNS destructive disease. Therefore in these patients elevated CPK-BB values should be considered relatively specific for hemorrhagic lesions and CNS the likely source of CPK-BB elevations. HAMBLETON and WiggLES-
WORTH [10] have clearly shown that PIVH originates in the subependymal layer as a result of capillary rupture or venous stasis secondary to hypercapnia and hypoxia. The hypothesis that in our patients the CNS injury occurs in the early perinatal period is confirmed by the results obtained at time of birth. The regularity of high $\mathrm{CPK}-\mathrm{BB}$ values at $\mathrm{T} 0$ suggests that a process is set in motion near the time of birth and culminates in PIVH. Moreover, in our study, infants with PIVH had a significantly lower Apgar Score at one minute of life compared to those without PIVH. Perinatal hypoxia and ischemia are factors that may predispose the premature infant to PIVH [23] as confirmed by elevated CPK-BB values observed in our patients immediately after delivery. We were unable to identify a second peak on the second or third day of life as described by SHIELDS et al [18]. Early perinatal cell destruction results in release of CPK-BB but serum enzymatic levels decreased in our collective rapidly from 4 to 10 hours of life. In accordance with some experimental studies $[4,5]$ it is known that CPK-BB half-life is very short. This fact suggests that the assay should be performed soon after birth or soon after any asphyctic event to be of prognostic value. Our findings have useful practical implications regarding the management of very low birth weight infants. To program clinical trials for prevention of PIVH it is of major importance to delineate the real timing of occurrence of such lesions in a population at risk $[11,17]$. In this way a better understanding of the true etiologic factors of this condition may emerge, thus allowing identification of preventable ones.

\begin{abstract}
Precise diagnosis of peri-intraventricular hemorrhage (PIVH) requires brain real-time ultrasound imaging procedure (US). However, maximal diagnostic efficiency of US lies between day 4 and 14 since fresh blood may initially appear sonolucent. Because of this supposed interval required for clot formation to become visible on US, serum CPK-BB estimations were performed in the first 60 hours of life to determine precise biochemical timing of PIVH. A group of 50 preterm infants less than $1500 \mathrm{~g}$ birth weight (1120 $\pm 320 \mathrm{~g})$ and 34 weeks gestation $(30 \pm 3.7$ weeks $)$ was studied. Serial CPK-BB measurements were performed
\end{abstract}

in serum immediately after birth (T0), then serially at time T1 $(6-10 \mathrm{~h}), \mathrm{T} 2(20-30 \mathrm{~h}), \mathrm{T} 3(40-60 \mathrm{~h})$. The incidence of PIVH diagnosed on the third day of life was $30 \%$. Total CPK-BB values at T0 in infants who developed PIVH were significantly higher than those of patients without cerebral bleeding $(70.8 \pm 30.5$ vs $20.9 \pm 10.7 \mathrm{U} / 1)(\mathrm{p}<0.05)$. The same statistically significant results were not observed analysing the CPK$B B$ values at $T 1, T 2$ and $T 3$.

These results suggest that most pathological conditions responsible for enzyme release occur in the pre- or perinatal period.

Keywords: Brain specific Creatine Kinase isoenzyme, peri-intraventricular hemorrhage, preterm infants. 


\section{Zusammenfassung}

Biochemische Erfassung von peri-intraventrikulären Blutungen durch postnatale CPK-Bestimmungen

Die präzise Diagnose der peri-intraventrikulären Blutung (PIVH) wird heute mit der cerebralen Ultraschalluntersuchung erreicht. Jedoch zeigt auch die Ultraschalluntersuchung ihre maximale diagnostische Spezifität erst zwischen dem 4. und 14. Tag, dies weil frisches Blut initial echoarm ist. Um in diesem Intervall, indem es durch die Thrombinausbildung zu einer zunehmenden Echodensität im Ultraschall kommt, eine PIVH diagnostizieren zu können, wurden CPKBB Bestimmungen im Serum durchgeführt. Eine Gruppe von 50 Frühgeborenen mit einem mittleren Geburtsgewicht unter $1500 \mathrm{~g}(1120 \pm 320)$ und einem mittleren Gestationsalter unter $34(30 \pm 3,7)$ Wochen wurde studiert. Die serienmäßigen CPK-BB Bestim- mungen wurden unmittelbar nach der Geburt (T0) ein zweites Mal mit 6-10 Stunden (T1), ein drittes Mal mit 20-30 Stunden (T2) und ein viertes Mal mit 4060 Lebensstunden (T3) durchgeführt.

Die Inzidenz der nach dem 3. Tag sonographisch diagnostizierten PIVH betrug $30 \%$.

Die CPK-BB Werte zum Zeitpunkt T0 waren in der Gruppe, der sonographisch festgestellten PIVH signifikant höher als bei der Gruppe ohne PIVH (70,8 $\pm 30,5)$ versus $(20,9 \pm 10,7)$ mit $p<0,05$. Es fanden sich keine signifikanten Unterschiede, wenn die CPKBB Werte zum Zeitpunkt T1, T2 und T3 miteinander verglichen wurden.

Diese Resultate zeigen, daß die meisten pathologischen Prozesse, die zu einer Enzymfreisetzung führen, ihren Ursprung in der prae- oder perinatalen Periode haben.

Schlüsselwörter: Frühgeborene, hirnspezifisches Kreatinkinase-Isoenzym, peri-intraventrikuläre Blutung.

\section{Résumé}

Le timing biochinique des hémorrage peri-intraventriculaires mesuré avec l'enzyme CPK-BB

La diagnostic précis de l'hémorragie peri- intraventriculaire se fait aujourd'huipar la sonographie cerebrale. Pourtant efficacité diagnostique maximale de la sonographie cérebrale se situe seulement entre le 4ième et le 14ième jours en raison de l'echogenicité faible du sang frais. Considérant cet intervalle nécessaire pour rendre visible la formation thrombotique à la sonographie, nous avons ajoutéune mésure de la CPK-BB afin de déterminer le temps d'apparition de la PIVH. Un groupe de 50 enfants preematurés d'un poids inférieur à $1500 \mathrm{~g}(1120 \pm 320)$ et avec un âge gestationel moyen de $30 \pm 3,7$ semaines a été éxaminé.

La mesure en série de la CPK-BB était éffectuée pour une première fois peu après la naissance (T0), une deuxième fois après 6 à 10 heures (T1), une troisième fois après 20 à 30 heures $(\mathrm{T} 2)$ et une dernière fois à l'âge de 40 à 60 heures (T3).

La diagnostic sonographique de la PIVH ce faisait chez $30 \%$ des enfants après la troisième jours de vie.

La valeur de la CPK-BB au T0 a montré une élévation significative chez les enfants avec PIVH, les valeurs moyenne étant 70,8 $\pm 30,5$ pour les enfants avec PIVH et $20,9 \pm 10,7$ pour les enfants sans PIVH.

Nous avons pas trouvé une différence significative dans les valeurs prises au T1, T2 et T3.

Ces résultats indiquent que les conditons pathologiques créant une augmentation d'enzyme libre ont lieu durant la période prae- ou périnatale.

Mots-clés: Enfants prématurés, hémorragie peri-intraventriculaire, isoenzyme cérébral de la créatine kinase.

Acknowledgements: The authors wish to thank the nurses of the Neonatal Intensive Care Unit for their valuable cooperation and Prof. Dr. H. KelLER and coll. (Institut für Klinische Chemie und Hämatologie, St. Gallen, $\mathrm{CH}$ ) for providing laboratory assistance.

\section{References}

[1] Amato M, R Gambon, H Howald, G von MurALT: Correlation of raised cord blood CK-BB and the development of peri-intraventricular hemorrhage in preterm infants. Neuropediatrics 17 (1986) 173

[2] Amato M, B Straume: Iridopupillarmembran zur Bestimmung des Gestationsalters des Frühgeborenen. Gynaekol Rundsch 21 (1981) 55

[3] Ballard J, K Kazmaier, H Driver: A simplified assessment of gestational age. Pediatr Res 11 (1977) 374
[4] BeCKer M, K MenzeL: Brain typical creatine kinase in the serum of newborn infants with perinatal brain damage. Acta Paediatr Scand 67 (1978) 177

[5] BeLton NR: Creatine phosphokinase. Blood and CSF levels in newborn infants and children. Arch Dis Child 45 (1970) 600

[6] BUCHER T, W BENDER, R FundelE: Quantitative evaluation of electrophoretic allo and isoenzyme patterns. FEBS lett. 115 (1980) 319 
[7] De Crespigny L, R Mackay, L Murton, R Roy, P RoBINSON: Timing of neonatal cerebrovascular hemorrhage with ultrasound. Arch Dis Child 57 (1982) 231

[8] Fernandez F, A Verdu, J Quero, A Perez-HiGUERAS: Serum CPK-BB isoenzyme in the assessment of brain damage in asphyctic term infants. Acta Paediatr Scand 76 (1987) 914

[9] FuJimura M, DM SAlisbury, R Robinson: Clinical events relating to intraventricular hemorrhage in the newborn. Arch Dis Child 54 (1979) 409

[10] G Hambleton, JS Wigglesworth: Origin of intraventricular hemorrhage in the preterm infant. Arch Dis Child 51 (1976) 651

[11] Ment L, C Duncan, R Ehrenkranz, R Lange, K TAYloR, C KleINMAN, D ScotT: Intraventricular hemorrhage in the preterm neonate: timing and cerebral blood flow changes. J Pediatr 194 (1984) 419

[12] Mc Donald M, B Koops, M Johnson, M GugGENHEIM, C RUMACK, S MrTCHELl, W HATHAWAY: Timing and antecedents of intracranial hemorrhage in the newborn. Pediatrics 74 (1984) 32

[13] NAEYL R, E Peters: Antenatal hypoxia and low IQ values. AJDC 141 (1987) 50

[14] Pape K, G Cersick, M Houang, R Blackwell, A Sherwood, R ThOBURN, E ReYNolds: Ultrasound detection of brain damage in preterm infants. Lancet I (1979) 1261

[15] Papile L, J Burstein, H Koffler: Incidence and evaluation of subependymal and intraventricular hemorrhage: a study of infants with less than 1500 gm. J Pediatr 92 (1978) 529

[16] Partridge J, D Babcock, J Steichen, B Han: Optimal timing for diagnostic cranial ultrasound in low birth weight infants: detection of intracranial hemorrhage and ventricular dilation. $\mathrm{J}$ Pediatr 102 (1983) 281
[17] Perlman J, J Volpe: Cerebral blood flow velocity in relation to intraventricular hemorrhage in the premature newborn infant. J Pediatr 100 (1982) 956

[18] ShIELds W, R Feldman: Serum CK-BB isoenzyme in preterm infants with periventricular hemorrhage. J Pediatr 100 (1982) 464

[19] Silverboard G, M Horder, P Ahmann, A lazZARA, J SCHWARTZ: Reliability of ultrasound in diagnosis of intracerebral hemorrhage and posthemorrhagic hydrocephalus: comparison with computed tomography. Pediatrics 66 (1980) 507

[20] SzYMONOWICZ W, V Yu: Timing and evolution of periventricular hemorrhage in infants weighing $1250 \mathrm{~g}$ or less at birth. Arch Dis Child 59 (1984) 7

[21] Tsiantos A, L Victorin, JP Relier, H Dyer, A BRILL, M STAHLMAN: Intracranial hemorrhage in the prematurely born infant. J Pediatr 85 (1974) 854

[22] Walsh P, R Jedeikin, G Ellis, R Primhak, S MAKELA: Assessment of neurologic outcome in asphyxiated term infants by use of serial CK-BB isoenzyme measurement. J Pediatr 101 (1982) 988

[23] Wigglesworth JS, KE PAPE: An integrated model for hemorrhagic and ischemic lesions in the newborn brain. Early Human Dev 2 (1978) 179

Received October 12, 1989. Accepted October 23, 1989.

PD Dr. med. Maurizio Amato

Neonatologie

Universitäts-Frauenklinik

Schanzeneckstr. 1

CH-3012 Bern

Switzerland 